\title{
簡易ボタンホール作製法
}

\author{
飯島 真 - ${ }^{1}$ 岡田 - 義 水盛邦彦 $^{2}$ 大塚 恵子 ${ }^{3}$

吉田 好徳 丸山範 晃 ${ }^{2}$ 丸山高史 ${ }^{2}$ 阿部 雅 紀 ${ }^{2}$ \\ 小川 千 恵 ${ }^{1}$ \\ 赤塚幸クリニック ${ }^{1}$ 日本大学医学部内科学系腎臓高血厓分泌内科学分野 ${ }^{2}$ \\ 日本大学医学部附属板橋病院透析室 ${ }^{3}$
}

キーワード : ボタンホール, 血液透析, 穿刺痛, 医療安全

〈要旨〉

われわれは, Twardowski らの方法と當間らの方法を組み合わせた簡易ボタンホール（BH）作製法を考案し，そ の安全性と有用性について検討した. 週 3 回血液透析を継続している安定期外来患者で, 文書による同意が得られ た 9 名（男性 6 名, 女性 3 名, 年齢 $62.3 \pm 17.1$ 歳, 原疾患 : 糖尿病性腎症 5 名, 慢性糸球体腎炎 4 名）を対象とし た. 簡易 BH 作製法は, 透析開始時通常の穿刺針で穿刺し, 次回以降の透析開始時, 穿刺孔に形成された痂皮を剥 がし，前回と同じスタッフが同じ穿刺針を用いて同一部位に同一方向で反復穿刺し，穿刺抵抗が軽減したと感じる まで繰り返した. 穿刺抵抗が軽減した時点をルート完成と判断し, 次回透析より BH 専用針を使用し, 挿入を行っ た. 1 例が挿入困難で再ルートを作製したため, 10 回の作製回数で検討した. 穿刺抵抗が軽減するまでの穿刺回数 は, $3.3 \pm 0.3$ 回であり, $80 \%$ が 3 回の穿刺で BH を作製できた. なお, BH 観察期間は 1 10 か月であるが, 全症例 とも，感染やドロップアウトはなく BH 挿入を現在も継続中である. 簡易 BH 作製法は, 安全に施行でき, Twardowski らの方法の欠点である穿刺孔の広がりおよび當間らの方法の欠点である高コストも改善できた. BH 挿入 は針刺し事故の防止にもつながるため, 医療安全の面からも推奨できると考えられた.

\section{Simple buttonhole method}

Shinichi lijima', Kazuyoshi Okada², Kunihiko Mizumori, Keiko Otsuka³, Yoshinori Yoshida², Noriaki Maruyama', Takashi Maruyama², Masanori $\mathrm{Abe}^{2}$ and Chie Ogawa'

Akatsuka-Saiwai Clinic ${ }^{1}$; Division of Nephrology, Hypertension and Endocrinology, Department of Medicine, Nihon University School of Medicine ${ }^{2}$; Department of Dialysis, Itabashi Hospital of Nihon University School of Medicine $^{3}$

Key words : buttonhole, hemodialysis, needle pain, medical safety

〈Abstract〉

We developed a new simple buttonhole $(\mathrm{BH})$ method combining Twardowski's method and Toma's method. In this study, we evaluated the usefulness and safety of our method. We enrolled hemodialysis patients who were clinically stable, and receiving outpatient dialysis 3 times per week. Nine patients (male/female :6/3, age :62. 3土 17. 1 years, primary disease : DM 5, CGN 4) were enrolled. Written informed consent was obtained from each patient. A simple $\mathrm{BH}$ was made by repeated cannulation at the same site and in the same direction as the initial cannulation. To ensure precise repitition of the procedure in each patient, cannulation was performed by the same staff using the same type of needle. We repeated cannulation until the resistance to needling decreased, at which point, we considered the establishment of the matured $\mathrm{BH}$ route complete. Thereafter, we used a dull needle for the $\mathrm{BH}$ and started $\mathrm{HD}$. One patient needed to be re-routed due to difficulty in cannulation. Therefore, we evaluated a total of 10 procedures. Cannulation was repeated $3.3 \pm 0.3,80 \%$ and the total $\mathrm{BH}$ was generally completed by 3 repeated cannulations. All patients continue using the $\mathrm{BH}$ successfully and there has not been any

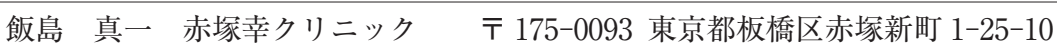

Shinichi Iijima Tel : 03-3976-6222 Fax : 03-3976-6233

〔受付日：2010 年 5 月 10 日, 受理日：2010 年 7 月 2 日〕 
report of infection or drop out during the period of observation (one to ten months). This simple BH method can improve the limitations of both Twardowski's method (expansion of BH) and Touma's (cost of BH creation), and can also be performed safely. The BH method can lead to the prevention of needle-stick injury and should be promoted for the sake of medical safety.

\section{緒言}

透析継続期間の長期化による穿刺頻度の増加および 高齢化や糖尿病による動脈硬化の進展などに伴い, 血 管損傷を予防することが長期内シャント管理には重要 である。Twardowski ら ${ }^{1,2}$ は，透析ごとに内シャント の穿刺部位を変えるのではなく, 同一部位に反復穿刺 することにより，穿刺痛が軽減される上，合併症の頻 度が低下し開存率が向上することを報告した。本法は ボタンホール $(\mathrm{BH})$ 穿刺と命名され, ボタンホールが 完成するまでの間，熟練したスタッフが同一部位から 長期間刺し続ける方法である。しかしこの方法は，鋭 い穿刺針で同一穿刺孔を正確に穿刺する必要があり， 穿刺孔が広がる可能性があることから，あまり普及し なかった。そこで當間ら ${ }^{3,4}$ は，血管表面近くまでしか 到達しないポリカーボネート製のピン（バイオホール スティック ${ }^{\circledR}:$ ニプロ社製) と先端が鈍の穿刺針を考案 し, 穿刺孔が一点しかできない $\mathrm{BH}$ 穿刺法を確立した. この方法はスティックを穿刺部位に留置することによ り，短期間のうちに $\mathrm{BH}$ を完成させる。そして $\mathrm{BH}$ 作 製中は，スティック留置部位を避けて鋭い穿刺針を穿 刺して透析を行い， BH 完成後には，先端が鈍の穿刺 針を刺入するものである. バイオホールスティック ${ }^{\circledR}$ は透析ごとに交換し，BH 挿入ルート完成までの 7〜 14 日程度の留置が必要であるが, 留置期間はアクセス
血管と皮膚の状態，穿刺するスタッフの技量などによ りそれぞれの施設の判断で短縮可能である ${ }^{4)}$. 今回, われわれは，Twardowski らの方法と當間らの方法を 組み合わせ，特別な器具が不要な簡易 $\mathrm{BH}$ 作製法を考 案し，その有用性と安全性について検討した。

\section{I ．対象および方法}

週 3 回血液透析を継続している安定期外来患者で, 文書による同意が得られ，穿刺痛が強度または内シャ ント血管の未発達例や返血側の静脈が細い症例など穿 刺困難な 9 名（男性 6 名，女性 3 名）を対象とした。 年齢 $62.3 \pm 17.1$ 歳 $(25 \sim 76$ 歳), 内シャント作製後 $20.4 \pm 17.1$ か月（2～58 か月）であり，原疾患は糖尿 病性腎症 5 名, 慢性糸球体腎炎 4 名であった（表 1). なお，結果は平均 $\pm \mathrm{SD}$ で表した。

ルート作製部位はシャント吻合部より距離をあけ, 腕の動きで皮膚と血管がなるべくずれなく，血管痛が 少ない部位で，血液リサーキュレーションが少なく， 血液透析治療効率が十分得られる 2 箇所を主に前腕で 選択した（症例 4 の返血側のみ上腕）。簡易 $\mathrm{BH}$ 作製 法（図 1）は透析開始時, 通常の外径 $16 \mathrm{G}$ カニューラ

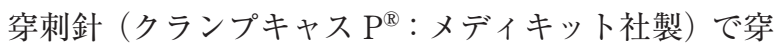
刺し, 次回以降の透析開始時, 穿刺孔に形成された痂 皮を $18 \mathrm{G}$ 注射針または木の綿棒を用いて丁寧に剥が し，前回と同じスタッフが同じ穿刺針を用いて同一部

表 1 簡易ボタンホール作製症例

\begin{tabular}{c|c|c|c|c|c|c|c}
\hline 症例 & 性別 & 年齢 & 原疾患 & $\begin{array}{c}\text { シャント } \\
\text { 使用月数 }\end{array}$ & 穿刺回数 & $\begin{array}{c}\text { 使用 } \\
\text { 穿刺針 }\end{array}$ & $\begin{array}{c}\text { BH } \\
\text { 使用月数 }\end{array}$ \\
\hline 1 & 女 & 25 & 慢性腎炎 & 2 & 3 & PN & 1 \\
\hline 2 & 男 & 70 & 慢性腎炎 & 9 & 4 & PN & 1 \\
\hline 3 & 女 & 53 & 慢性腎炎 & 12 & 3 & PN & 6 \\
\hline 4 & 男 & 73 & 糖尿病 & 12 & 3 & DN & 1 \\
\hline 5 & 男 & 67 & 糖尿病 & 12 & 3 & DN & 4 \\
\hline 6 & 男 & 76 & 糖尿病 & 20 & 3 & PN & 7 \\
\hline 7 & 女 & 71 & 糖尿病 & 25 & 3 & PN & 10 \\
\hline 8 & 男 & 41 & 糖尿病 & 42 & 3 & DN & 5 \\
\hline 9 & 男 & 74 & 慢性腎炎 & 58 & 3 & DN & 4 \\
\hline
\end{tabular}

$\mathrm{PN}$ : ペインレスニードル ${ }^{\circledR}$

DN：ダルニードル® 


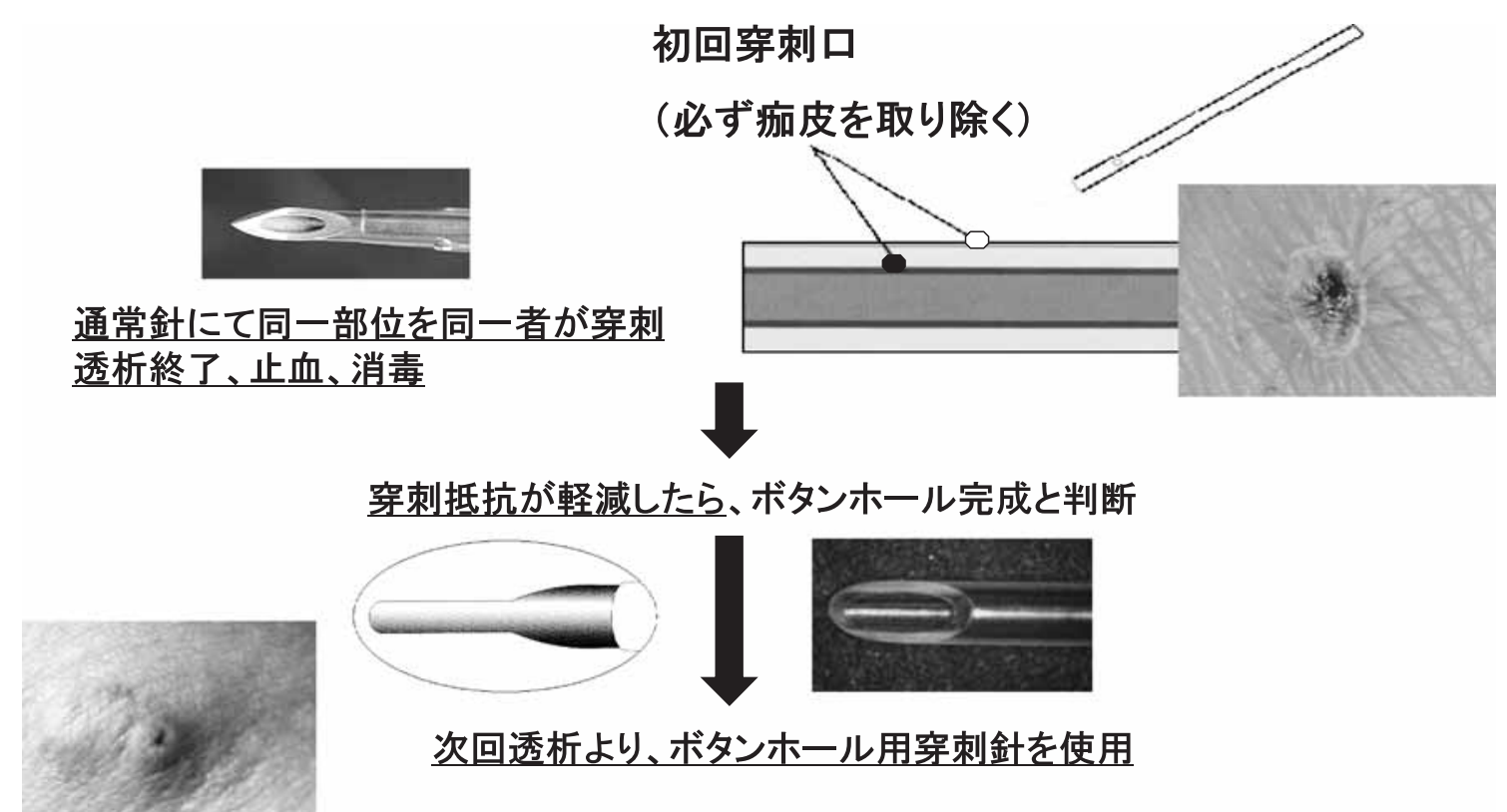

図 1 簡易ボタンホール作製方法

位で同一方向に反復穿刺した。この穿刺作業を担当し た 1 人のスタッフが穿刺抵抗の軽減を感じるまで繰り 返した．穿刺抵抗が軽減した時点をルート完成と判断 し, 次回透析より通常のカニューラ穿刺針は使用せず, 先端が鈍で鋭くカットしてない外径 $16 \mathrm{G}$ およよび $17 \mathrm{G}$ ダルニードル（DN； AVF ニードル ${ }^{\circledR}$, セーフレットカ ニューラ $\mathrm{GA}^{\circledR}$, ニプロ社製) または, 先端が丸いペイ

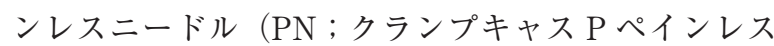

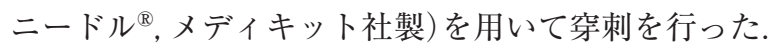
DN を十分発達したシャント血管や壁が厚い症例に, PNを細いシャント血管や静脈など血管壁が薄い症例 に使い分けて，BH 挿入を行った。な扮，皮膚消毒は $10 \%$ ポビドンヨード液またはステリコット ${ }^{\circledR} \alpha$ を使用 した。

\section{II. 結 果}

症例 4 に执いて，上腕の返血側静脈が皮膚表面から 深部にあり，血管と皮膚とのずれが生じやすく㨂入困 難であったため, 作製 15 日後に $2 \mathrm{~cm}$ 末梢で上腕の同 一静脈に再ルートを作製した。 そこで, 10 回の作製回 数で検討したところ, 穿刺抵抗が軽減するまでの穿刺 回数は, $3.3 \pm 0.3$ 回であった. 通常のカニューラ穿刺 針での同一部位反復穿刺 $\mathrm{BH}$ 作製法では， $80 \%$ が 3 回 の穿刺で BH を作製でき，4回目に BH 専用針にて挿 入できたが, 最長は 5 回の穿刺が必要であった (表 1). なお， $\mathrm{BH}$ 継続期間は 1 10 か月であるが，全症例と
も，感染やドロップアウトはなく $\mathrm{BH}$ 挿入を現在も継 続中である。

\section{III. 考 察}

Twardowski ら ${ }^{1,2)}$ の方法と當間ら ${ }^{3,4)}$ の方法を組み 合わせた簡易 BH 作製法により， 80\%の症例が 1 週間 後に BH を作製できた. Twardowski らの方法は，数 週間にわたり熟練したスタッフが同一部位で同一方向 に鋭い穿刺針で穿刺を繰り返して BH を作製する。し かし，正確に同一孔を穿刺するのは困難であり，鋭い 穿刺針にて穿刺を重ねることによる穿刺孔の拡大が䯚 念された，われわれの方法では，BH を少ない穿刺回 数（3〜5 回）で作製することによりこの欠点を改善で きると思われる。，一方，當間ら ${ }^{3,4)}$ の BH 作製方法は, 穿刺針を抜去したルートに沿って画鋲型のバイオホー ルスティックを挿入・留置し, 以後, ルートが完成す るまで 1 2 週間は透析ごとに新しいスティックと交 換する。このスティック ${ }^{\circledR} は$ 保険適用外であり, 1 回 4,000 円かかるため, 週 3 回の透析患者では 3 6 回使 用することになり 12,000〜24,000 円のコストが必要 になる。また， $\mathrm{BH}$ 作製中はスティック留置部位を避 けて，通常の穿刺針で穿刺して透析を行い，1２週間 経過後の第 1 回目の BH 穿刺は通常の鋭い穿刺針を使 用しなければならない，われわれの方法では，當間ら の方法の欠点である高コストは，スティックを使用し ないため回避できる. 
疼痛の軽減〜消失，止血時間の短縮，穿刺失敗時の 出血なし，血管損傷の軽減，血管刺入孔周囲の肥厚と 狭窄なしなどの特徴がある $\mathrm{BH}$ 挿入は, 長期内シャン 卜管理のために有用である ${ }^{4}$. しかし，コスト面など から敬遠されがちである。簡易 BH 作製法は，コスト の問題を解決でき, 特別な器具が不要で $\mathrm{BH}$ の作製や 維持管理も容易であった。

全症例において, BH 挿入は観察期間に感染症など の合併をきたすこともなく安全に施行できており，穿 刺困難な症例や穿刺痛が強い症例に対しても有用であ るだけではなく, 針刺し事故の防止にもつながるため, 医療安全の面からも推奨できると考えられた。

\section{文献}

1) Twardowski $Z$, Kubara H : Different sites versus constant sites of needle insertion into arteriovenous fistulas for treatment by repeated dialysis. Dialysis \& Transplantation 8:973-980, 1979

2) Twardowski $Z$ : Constant site (Buttonhole) method of needle insertion for hemodialysis. Dialysis \& Transplantation $24: 559-560,1995$

3) Toma S, Shinzato T, Fukui H, Nakai S, Miwa M, Takai I, Maeda K: Timesaving method to create fixed puncture route for buttonhole technique. Nephrol Dial Transplant $18: 2118-2121,2003$

4）當間茂樹：アクセスの上手な使い方一 $\mathrm{BH}$ 穿刺。腎と 透析 $58: 416-421,2005$ 